\title{
Air pollution tolerance index: An approach towards the effective green belt around Kathmandu metropolitan city, Nepal
}

\author{
Kiran Kanwar ${ }^{1}$, Man K. Dhamala ${ }^{1,2}$ and Rejina Maskey-Byanju ${ }^{2^{*}}$ \\ ${ }^{1}$ Golden Gate International College, Kathmandu \\ ${ }^{2}$ Central Department of Environmental Science, Tribhuvan University
}

\begin{abstract}
Road vegetation is an effective way to mitigate road generated particulates. Green belts with high Air Pollution Tolerance Index (APTI) value in the urban centers play an important role in the amelioration of the air quality. The APTI of the trees with higher abundance were examined for bio-chemical parameters such as $\mathrm{pH}$, ascorbic acid, total chlorophyll and relative water content. The APTI value of tree species varied from 5.56 ( Punica granatum) to 79.99 (Populous deltoids). Higher the APTI value, higher is the tolerance towards air pollution. Among the tree species, Jacaranda mimosifolia, Pinus roxburghi, Ficus benjamin, Celtis australis, Alnus nepalensis, Callistemon lanceolatus, Schima wallichi, Pyrus pyrifolia and Punica granatum were found sensitive, whereas Prunus persia, Populus deltoides, Thuja sp. and Grevillea robusta were found to be the most tolerant species. The green belts constituting higher number of tolerant to moderately tolerant species of trees results in better air pollution sink and air quality refinement. In order to find plants with good APTI, further extensive studies should be carried out and valley plantation program should give priority of those plants having higher APTI value.
\end{abstract}

Key words: APTI, Environment management, Green belt, Sensitive

\section{Introduction}

Air pollution is a regional and global problem and is one of the major factors deteriorating the quality of life in urban areas, making people more vulnerable to diseases all over the world (Esfahani et al., 2013; Makhelouf , 2009). Cities are responsible for the emission of $71 \%$ of ener gy related to global greenhouse gases worldwide (Hoornweg et al., 2011) and vehicular emission is one of the major contributors for emission of combustion gases, due to increasing dependency on private transportation (Liu \& Ding, 2008; Tiwari et al., 2011). Road traffic is the main cause for air pollution in the metropolitan cities resulting in environmental as well as health problems due to har mful emissions (Gidde \& Sonawane, 2012). Vegetation is always considered as an indicator for an effective sink for $\mathrm{HF}, \mathrm{SO}_{2}, \mathrm{Cl}_{2}, \mathrm{NO}_{2}$ and $\mathrm{O}_{3}$ and to a less extent PAN (Peroxyacetyl Nitrate) during the growing season and also for removal of $\mathrm{HCl}$ resulting in reduction of concentration of atmospheric pollutants (HILL, 1071).

Plantations on the street canyons can result in reduction of about $40 \%$ for $\mathrm{NO}_{2}$ and $60 \%$ for particulate matter (PM) (Pugh et al., 2012). The removal of particulate matter occurs both day and night (as particles are intercepted by leaf and bark sur faces)

*Corresponding author, email address: rmaskey@cdes.edu.np throughout the year, whereas the effect on ozone $\left(\mathrm{O}_{3}\right), \mathrm{SO}_{2}$ and $\mathrm{NO}_{2}$ is during the day period (in leaf season), when trees are transpiring water and carbon monoxide removal occurs both day and night of the leaf-in-season (Nowak et al., 2006).

Bio-monitoring of air pollution and its impact on plants biochemical parameters is highly relevant in air pollution science ( $\mathrm{R}$ ai et al., 2013). The parameters lik e leaf $\mathrm{pH}$, relative water content, chlorophyll content, and ascorbic acid content combinely suggested as the best index of the susceptibility levels of plants known as the air pollution tolerance index (APTI) (Kuddus et al., 2011), as plant sensitivity and tolerance varies with change in these parameters (Liu \& Ding, 2008; Singh \& Verma, 2007). Combination of these parameters gives more reliable results than those obtained by individual parameters (Bora \& Joshi, 2014). Plantation along the roadside may seem as an easy job, but all the factors that can affect a tree species should be considered beforehand for its sustainability. Air pollutants can affect plants directly through leaves or indirectly through soil acidification (Abida \& Harikrishna, 2010). Air pollution can have major effect on photosynthetic system, leaf longevity and on the patter $n$ of carbon allocation within plants (Kuddus et al., 2011) and also can cause increased 
permeability resulting in early senescence of leaves (due to loss of water and dissolved nutrients) (Masuch et al., 1988). Road side vegetations are even more sensitive, as they are in direct contact of the pollutants, which eventually will harm them adversely and make life difficult. Evaluation of the tolerance level of the plants can provide an effective basis for the plantation of trees in air polluted areas, necessary for longevity and sustainable planning of green belts and amelioration of air quality. This study can be a basis for identification of the tolerant trees that can act as a sink as well as screen air pollution and helpful for future plantations, especially for green belt construction in the valley.

\section{Site description:}

Kathmandu Valley lies at $1300 \mathrm{~m}$ asl, located between latitudes $27^{\circ} 32^{\prime} 13^{\prime \prime} \& 27^{\circ} 49^{\prime} 10^{\prime \prime}$ north and longitudes $85^{\circ} 11^{\prime} 31^{\prime \prime} \& 85^{\circ} 31^{\prime} 38^{\prime \prime}$ east. The valley is bowl shaped being surrounded by Mahabharat range on all sides. South and south westerly wind dominate the valley (Pradhan et al., 2012). The calm and low wind speeds in the valley causes poor dispersion conditions and the bowl-shaped topography makes the area more prone to air pollution (Pradhan et al., 2012, Shrestha, 2001). Kathmandu city is amongst one of the world's most polluted cities (Chattopadhyay et al., 2010), particulate matter being one of the major pollutant (Shrestha, 2001). The number of vehicles has increased tremendously with the rate of $4.3 \%$ in the valley (Department of $\mathrm{T}$ ransport Management, 2014).

\section{Materials and Methods}

The abundant trees along the $27 \mathrm{~km}$ Ring Road side of the valley was observed and least abundant tree species were used as sample for analysis in the study. UN Park and forest patch within the premises of Buddhanilkantha School were selected as control sites and studied according to tolerant trees. Leaves were collected from the selected plant species in early mor ning. Plants were randomly selected and three replicates of fully matured leaves were used. Leaf samples were kept in polythene bag, in ice box and brought to the laborator $y$ for biochemical analysis. The laboratory work was conducted from A ugust to October. APTI value was calculated using the for mula (Eq. 1) (Chouhan et al., 2012; Thambavani et al., 2011).

Where,

$$
\text { APTI: } \frac{[\mathrm{A}(\mathrm{T}+\mathrm{P})+(\mathrm{R})]}{10} \quad \ldots 1
$$

$\mathrm{A}=$ Ascorbic acid content (mg/gm) (dry weight)

$\mathrm{T}=$ Total chlorophyll content (mg/gm)

$\mathrm{P}=\mathrm{pH}$ of leaf extract and

$\mathrm{R}=$ Relative water content (\%).

APTI values were categorized into three groups (Table 1)

(Thambavani \& Kumar, 2011).

Table 1 Category of tree species based on APTI

\begin{tabular}{ll}
\hline APTI value & Response \\
\hline $30-100$ & Tolerant \\
$29-17$ & Intermediate \\
$16-1$ & Sensitive \\
\hline
\end{tabular}

Total chlorophyll (TCh) was deter mined according to (Ar non, 1949) $1.0 \mathrm{gm}$ of fresh leaves blended and then extracted with 20.0 $\mathrm{ml}$ of $80 \%$ acetone and lef $\mathrm{t}$ for $15 \mathrm{~min}$. The liquid portion was decanted into another test tube and was centrifuged at 2,500 rpm for $3 \mathrm{~min}$. The supernatant was then collected and the absorbance was measured at $645 \mathrm{~nm}$ and $663 \mathrm{~nm}$ using a spectrophotometer. Calculations were done using the Eq. 2 and 3.

$$
\begin{aligned}
& \text { Chlorophylla }=(12.7 \mathrm{Dx} 6632.69 \mathrm{DX} 645 * \mathrm{~V}) / \text { 1000W mg/gm ... } 2 \\
& \text { Chlorophyllb }=(22.9 \mathrm{Dx} 6454.68 \mathrm{DX} 663 * \mathrm{~V}) / 1000 \mathrm{~W} \mathrm{mg} / \mathrm{gm} \ldots 3 \\
& \text { TCH = chlorophyll } \mathrm{a}+\mathrm{b}(\mathrm{mg} / \mathrm{gm})
\end{aligned}
$$

Where,

$\mathrm{Dx}=$ Absorbance of the extract at the wavelength Xnm

$\mathrm{V}=$ Total volume of the chlorophyll solution $(\mathrm{ml})$

$\mathrm{W}=$ Weight of the tissue extracted $(\mathrm{gm})$

Relative water content (RWC) was determined according to Sadeghian and Mortazaienezhad (2012) and calculated using Eq. 5.

$$
\mathrm{RWC}=(\mathrm{FW}-\mathrm{DW} / \mathrm{TW}-\mathrm{DW}) \times 100
$$

Fresh weight (FW) was obtained by weighing the leaves. The leaf samples were then immersed in water overnight and then blotted dry and then weighed to obtain the tur gid weight (TW). The leaves were then blotted to dryness and placed in oven at $105^{\circ} \mathrm{C}$ for 2 hours to obtain the dry weight (DW).

Ascorbic acid (AA) content was calculated using the spectrophotometric method according to Bajaj and K aur (1981). In which, about $1.0 \mathrm{gm}$ of the fresh foliage was put in a test-tube, $4.0 \mathrm{ml}$ oxalic acid - EDTA extracting solution was added; then $1.0 \mathrm{ml}$ of orthophosphoric acid and then $1.0 \mathrm{ml}$ of $5 \%$ sulphuric acid was added to this mixture, $2.0 \mathrm{ml}$ of ammonium molybdate was added and then $3.0 \mathrm{ml}$ of water. The solution was then allowed to stand for 15 minutes. After which the absorbance at $760 \mathrm{~nm}$ was measured with a spectrophotometer. The concentration of ascorbic acid in samples was calculated from standard ascorbic acid cur ve. Leaf extract $\mathrm{pH}$ was determined following the method of Chauhan et al. (2012). F or that, about $1.0 \mathrm{gm}$ of the fresh leaves was homogenized in $10 \mathrm{ml}$ de-ionised water. This mixture was filtered and the $\mathrm{pH}$ of the leaf extract was deter mined after calibrating pH-meter with buffer solution of $\mathrm{pH} 4$ and $\mathrm{pH} 9$.

\section{Results and Discussion}

The most abundant tree species along the Ring-road side were Gravellia robusta (1057), Jacaranda mimosifolia (903), Populas deltoids (707), Callistemon lanceolatus (241), Thuja sp. (193), Cinnamomum camphora (154) and Ficus elastica (112), whereas the least obtained species were Tudi (5), Ficus benjamin (4) and Punica granatum (2). Similarly, from the controlled sampling site; the forest of Buddhanilkantha School premises and UN-Park, Alnus nepalensis (56), Cinnamomum camphora (20) were found 
to be the most common tree and Schima wallichi (1), Quercus spp. (1) and Pyrus communis (1) were obtained as the species of least occurrence within the premises of Buddhanilkantha School and in the UN-Park Callistemon lanceolatus (21), Grevillea robusta (14) were obtained as the most abundant and Melia azedarach (1) and Jacaranda mimosifolia (1) as the least abundant in the park.

The abundant trees species from the polluted site (Ring Road) along with two least abundant trees were taken as sample species for the evaluation of the air pollution tolerance index (Table 2).

Relative water content (RWC) is the total water content in a given leaf relative to its fully tur gid or hydrated state (Bora \& Joshi, 2014). High amount of water content in plants mak es the plant species drought resistance (Chouhan et al., 2012; Sadeghian \& Mortazaienezhad, 2012). Plants with high RWC are more tolerant to air pollutants (Chouhan et al., 2012; Gharge \& Menon, 2012; Kuddus et al., 2011). The RWC in the sampled species ranged from 34.14\% to 92.30\%, with highest value in Thuja sp. (92.30\%) followed by Prumus persia (90.29\%) and Cinnamomum camphora (87.25\%) (Fig.1). Lower values were reported Callistemon lanceolatus (44.58\%) and Punica granatum (34.15\%) (Table 2). This results reveal that Prumus persia, Thuja sp. and Cinnamomum camphora are more drought resistance as well as more air pollutants stress resistance (among the studied samples). Relative water content of plants near polluted sites was found higher than those present in the non-polluted sites and also plants retain more water at polluted sites to become more tolerant (Bora \& Joshi, 2014). The samples of the controlled site represent lower RWC, ranging from $47.32 \%$ to $56.74 \%$ which is comparatively less than the majority of samples from polluted site.
Plants with high amount of water content is favorable to combat the adverse effects (Kuddus et al., 2011) and maintain the ecological balance, whereas plants with lower tolerance may lead to reduction in the transpiration rate resulting in damage to the leaf engine that pulls water up from the roots (Chouhan et al., 2012; Seyyednjad et al., 2011) and then the plants neither can uptake the minerals nor cool the leaf (Seyyednjad et al., 2011) destroying the whole plant system.

The chlorophyll content in the studied tree leaves ranged from $0.03 \mathrm{mg} / \mathrm{gm}$ to $0.60 \mathrm{mg} / \mathrm{gm}$ in the roadside trees along the Ringroad. This value exhibited greater in controlled site, i.e. 0.79 mg/gm (Fig. 2). Among the tree species, Punica granatum exhibited the highest chlorophyll content followed by Celtis australis, Pinus roxburghii and Cinnamomum camphora, whereas Jacaranda mimosifolia $(0.04 \mathrm{mg} / \mathrm{gm})$ and Ficus elastica ( $0.03 \mathrm{mg} / \mathrm{gm})$ exhibited the lowest chlorophyll content among the studied tree leaves (Fig. 2, Table 2).

The chloroplast is the primar y site of attack by air pollutants, affecting the leaf chlorophyll content (loss in the chlorophyll content) (Tripathi \& Gautam, 2007). Chlorophyll undergoes several photochemical reactions such as oxidation, reduction, reversible bleaching under stress conditions (Sharma et al., 2013) influenced by pollution level as well as other biotic and abiotic stresses. Depletion in chlorophyll content causes a decrease in productivity of plant due to decrease in photosynthetic activity (Seyyednjad et al., 2011) and subsequently plant exhibit poor vigor, affecting the tolerance of plants towards air pollution (Chinthala \& Khare, 2012; Singh \& Verma, 2007). Schima wallichi exhibited the highest chlorophyll content being far from the pollution (less pollutedcontrolled site) and representing high productivity of plant and functioning.

Table 2 Air pollution tolerance index (APTI) of tree species

\begin{tabular}{|c|c|c|c|c|c|c|c|}
\hline S.No. & Scientific Name & Common name & $\begin{array}{c}\text { Relative water } \\
\text { content }(\%)\end{array}$ & $\underset{(\mathbf{m g} / \mathbf{g m})}{\mathrm{pH}}$ & $\begin{array}{l}\text { Total Chlorophyll } \\
\text { (mg/gm) }\end{array}$ & Ascorbic acid & APTI \\
\hline 1. & Populus deltoides & Laharepipal & 80.59 & 6.1 & 0.36 & 111.35 & 79.99 \\
\hline 2. & Prunus persia & Aaru & 90.29 & 5.8 & 0.23 & 111.97 & 77.44 \\
\hline 3. & Grevillea robusta & Kalki & 67.55 & 6.0 & 0.43 & 41.01 & 33.24 \\
\hline 4. & Thuja sp. & Dhupi & 92.30 & 5.9 & 0.18 & 37.85 & 32.55 \\
\hline 5. & Cinnamomum camphora & Kapur & 87.25 & 6.1 & 0.47 & 29.45 & 28.16 \\
\hline 6. & Ficus elastica & Rubber plant & 71.63 & 6.2 & 0.03 & 29.49 & 25.67 \\
\hline 7. & Mussaenda grandiflora & Asharephool & 77.25 & 5.6 & 0.27 & 22.47 & 21.10 \\
\hline 8. & Eucalyptus alba & Masala & 69.71 & 5.1 & 0.54 & 20.46 & 18.55 \\
\hline 9. & Jacaranda mimosifolia & Siris & 79.38 & 4.6 & 0.04 & 15.27 & 15.09 \\
\hline 10. & Callistemon lanceolatus & Bottle brush & 44.58 & 6.1 & 0.42 & 8.82 & 10.25 \\
\hline 11. & Pinus roxburghii & Pine & 58.85 & 3.6 & 0.49 & 5.46 & 8.14 \\
\hline 12. & Ficus benjamina & Ficus & 58.55 & 4.6 & 0.29 & 3.51 & 7.57 \\
\hline 13. & Celtis australis & Khari & 41.52 & 6.7 & 0.54 & 1.99 & 5.59 \\
\hline 14. & Punica granatum & Anar & 34.15 & 4.9 & 0.60 & 3.86 & 5.56 \\
\hline
\end{tabular}




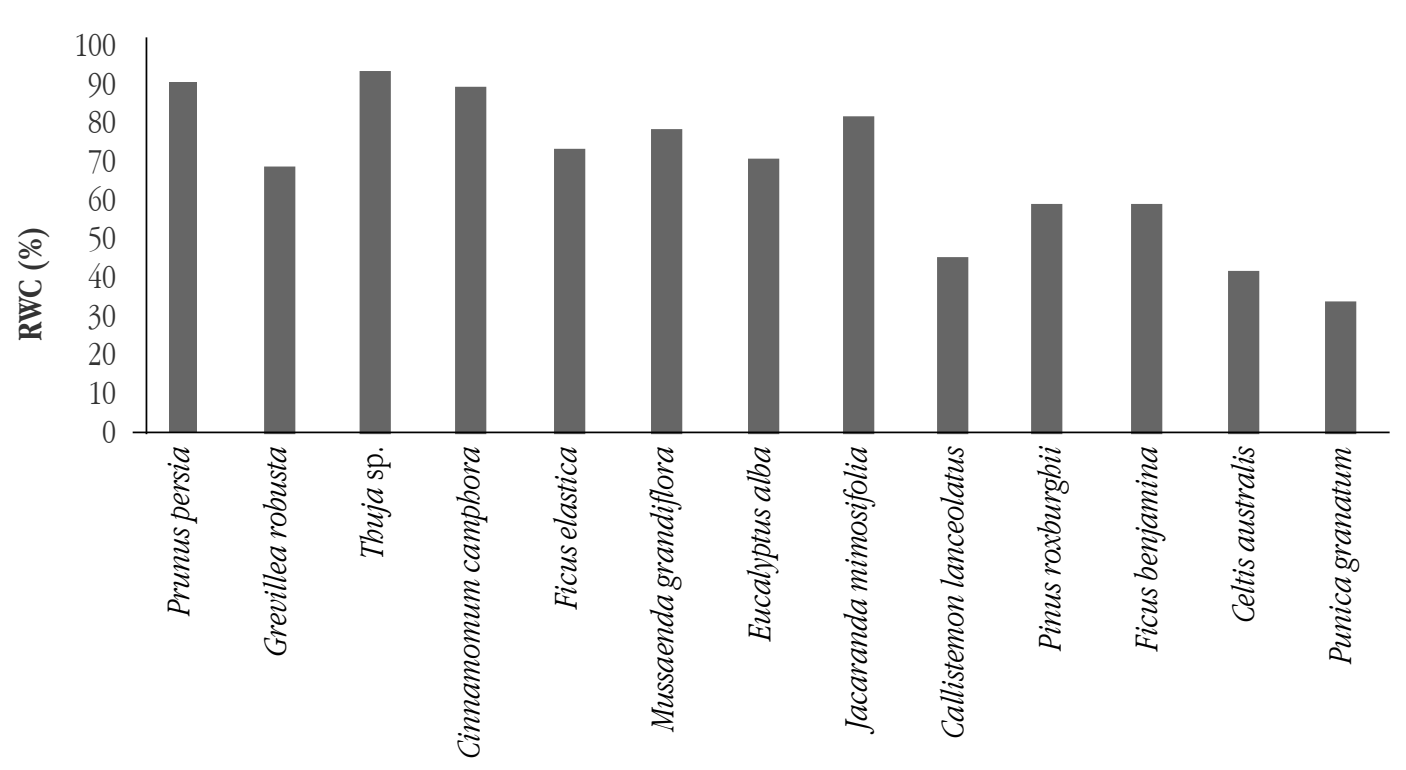

Figure 1 Variation in relative water content in the selected tree species

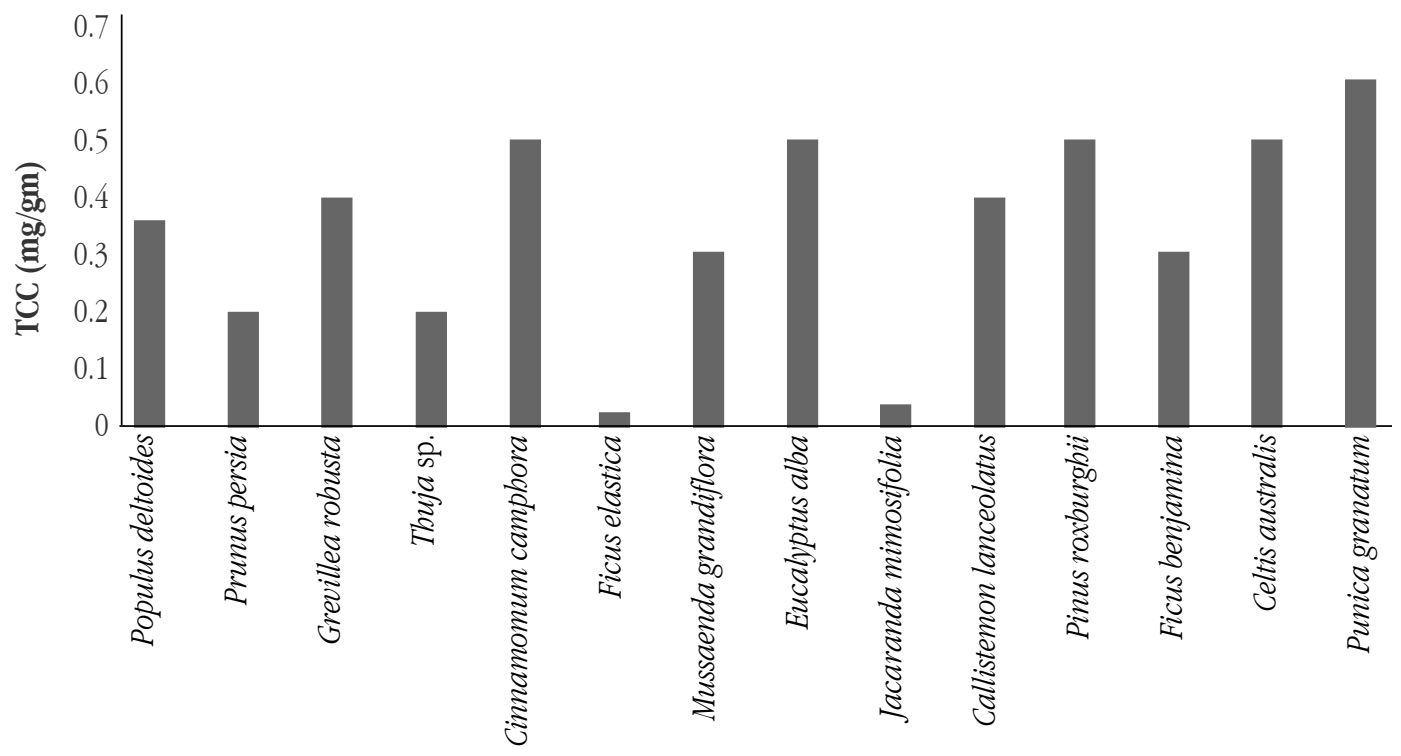

Figure 2 Variation in total chlorophyll content in the selected tree species

Ascorbic acid is an important antioxidant that is found in all plant parts (Keller \& Schwager, 1977; Singh et al., 1991). It plays a significant role in cell-wall synthesis, defense and cell division (Seyyednjad et al., 2011) and also protects chloroplasts and chlorophyll functions through its $\mathrm{pH}$ dependent reducing power (Singh et al., 1991). It influences resistance to adverse environmental conditions in plants against air pollution (Lima et al., 2000) to prevent the damaging effect in plant tissues (K apoor \& Bansal, 2013). High pollution load causes an increase in ascorbic acid content in plants, due to the increased rate of production of reactive oxygen species (ROS) during photo-oxidation process
(Lima et al., 2000; Tripathi \& Gautam, 2007) and also plays an important role in protection of chlorophyll from $\mathrm{H}_{2} \mathrm{O}_{2}$ induced damages (Singh \& Verma, 2007) .

The ascorbic acid content in the leaf extracts ranged from 1.99 $\mathrm{mg} / \mathrm{gm}$ to $111.97 \mathrm{mg} / \mathrm{gm}$. Most of the plants exhibited low ascorbic acid content in the leaves, which ranged from $20.0 \mathrm{mg} / \mathrm{gm}$ to 42.0 $\mathrm{mg} / \mathrm{gm}$ (Fig. 3). The decrease in the ascorbic acid content can be due to pollution exposure (Keller \& Schwager, 1977). Prunus persia showed the highest ascorbic acid content followed by Populus deltoides and Grevillea robusta, whereas Ficus benjamin 
and Celtis australis showed low ascorbic acid content. High pollution level in the air increases the phytotoxicity of plants (Singh \& Verma, 2007) by impinging a decrease in the ascorbic acid content which eventually results in increased susceptibility of plants to pollution. High ascorbic acid content in leaf represents a higher tolerance against air pollution load and higher resistance (Singh \& Verma, 2007). Higher the level of ascorbic acid content, more will be the tolerance toward air pollutants (Kousar et al., 2014; Kuddus et al., 2011).

$\mathrm{pH}$ is an important parameter of plant physiology to measure the air pollution tolerance index. Photosynthesis is strongly associated with the leaf $\mathrm{pH}$, the low leaf $\mathrm{pH}$ in the same species indicates

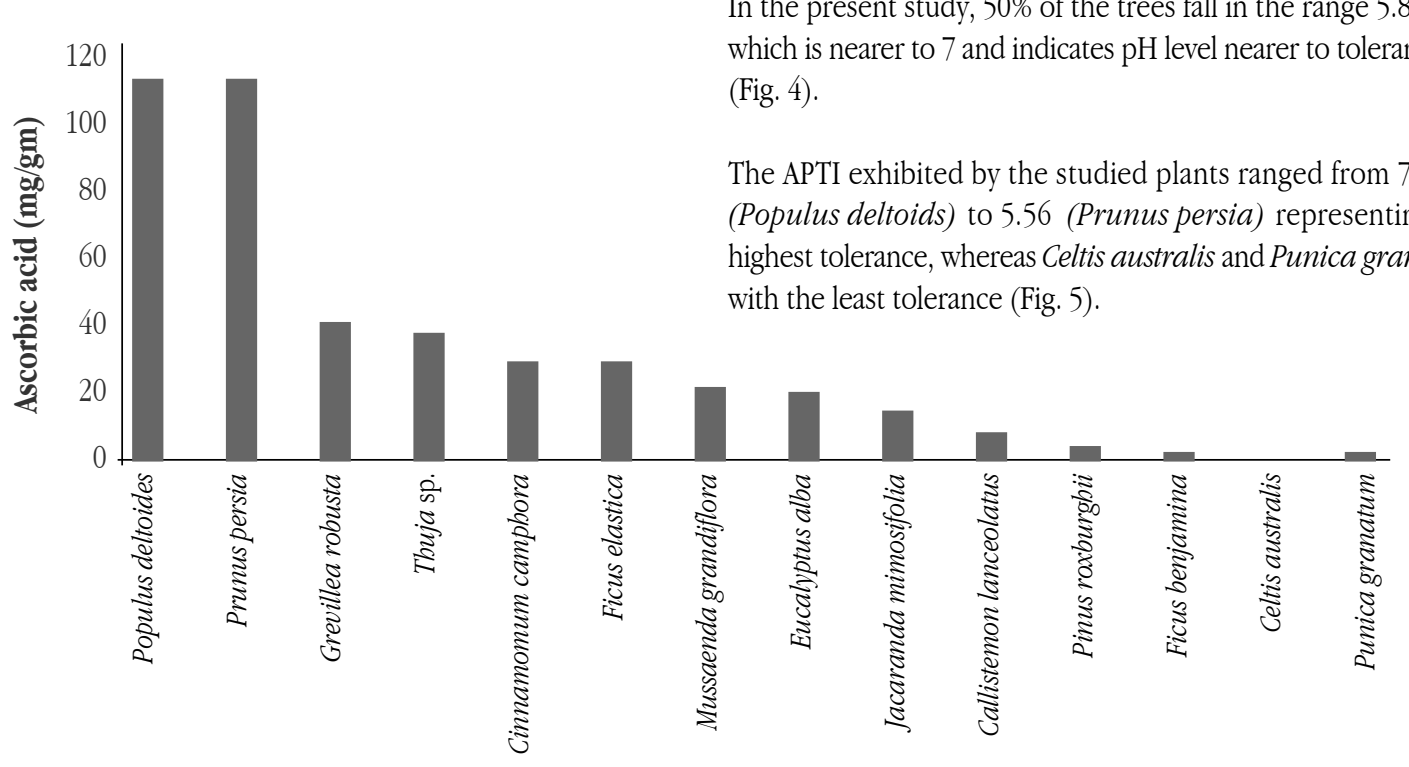

Figure 3 Variation in ascorbic acid content in the selected tree species

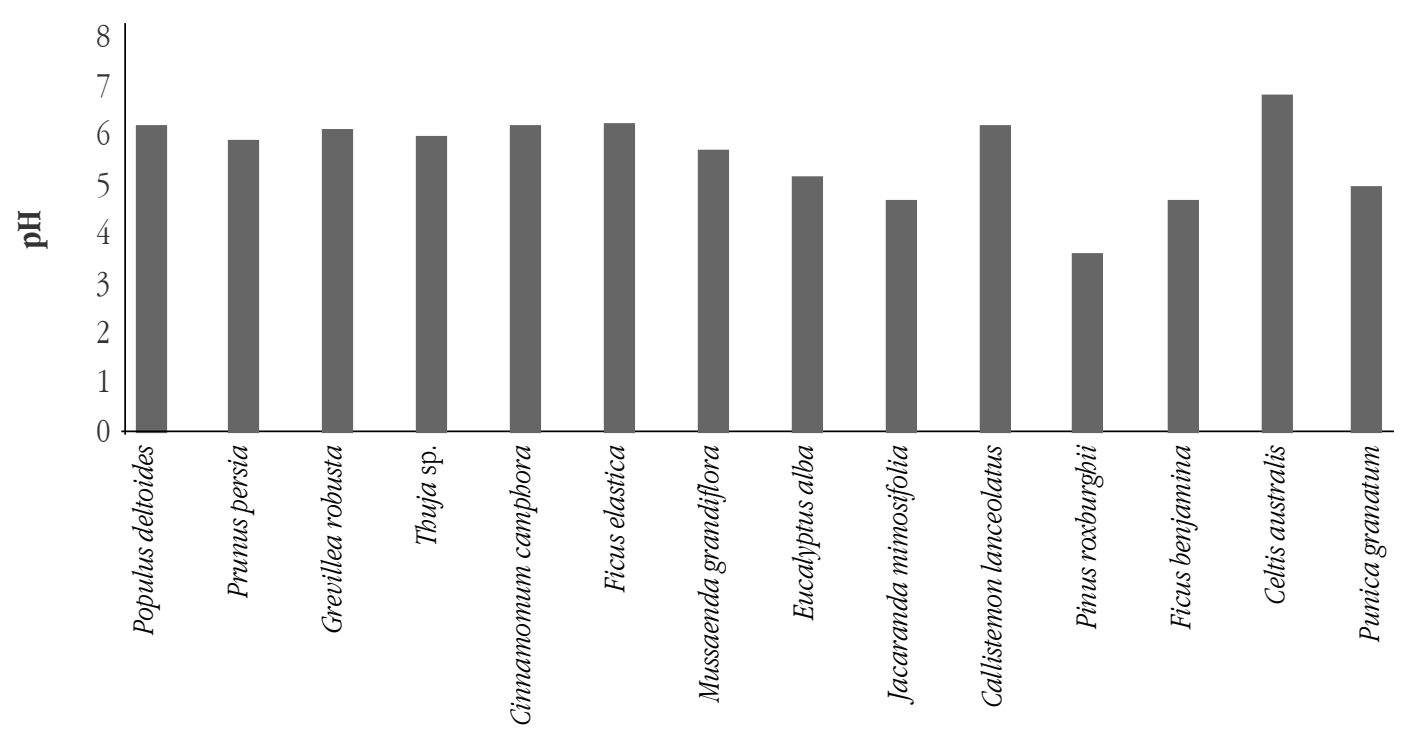

Figure 4 Variation in $\mathrm{pH}$ value in the selected tree species reduced photosynthetic rate (Chouhan et al., 2012). More acidic $\mathrm{pH}$ is more susceptible, whereas neutral $(\mathrm{pH} 7)$ and more basic $\mathrm{pH}$ are considered to be more tolerant (Singh \& V erma, 2007). The $\mathrm{pH}$ level of the studied plant leaves ranged from 3.6 to 6.7, with highest $\mathrm{pH}$ values in Celtis australis followed by Ficus elastica and lowest in Pinus roxburghii (Fig. 4). The lower leaf $\mathrm{pH}$, i.e. towards the acidic side, can be due to the presence of $\mathrm{S}_{2}$ and $\mathrm{NO}_{\mathrm{x}}$ in the air as the result of vehicular emissions (Choudhury \& Banerjee, 2009), showing this type of air pollution (Thambavani \& MA, 2011). According to Larcher (1995) plants sensitive towards $\mathrm{SO}_{2}$ and $\mathrm{NO}_{x}$ close the stomata faster when exposed to the pollutants. Higher level of $\mathrm{pH}$ in leaf extract indicates higher or increased tolerance level to air pollutants (Kuddus et al., 2011). In the present study, $50 \%$ of the trees fall in the range $5.8-6.0$, which is nearer to 7 and indicates $\mathrm{pH}$ level nearer to tolerant level The APTI exhibited by the studied plants ranged from 79.99 (Populus deltoids) to 5.56 (Prunus persia) representing the highest tolerance, whereas Celtis australis and Punica granatum with the least tolerance (Fig. 5). 


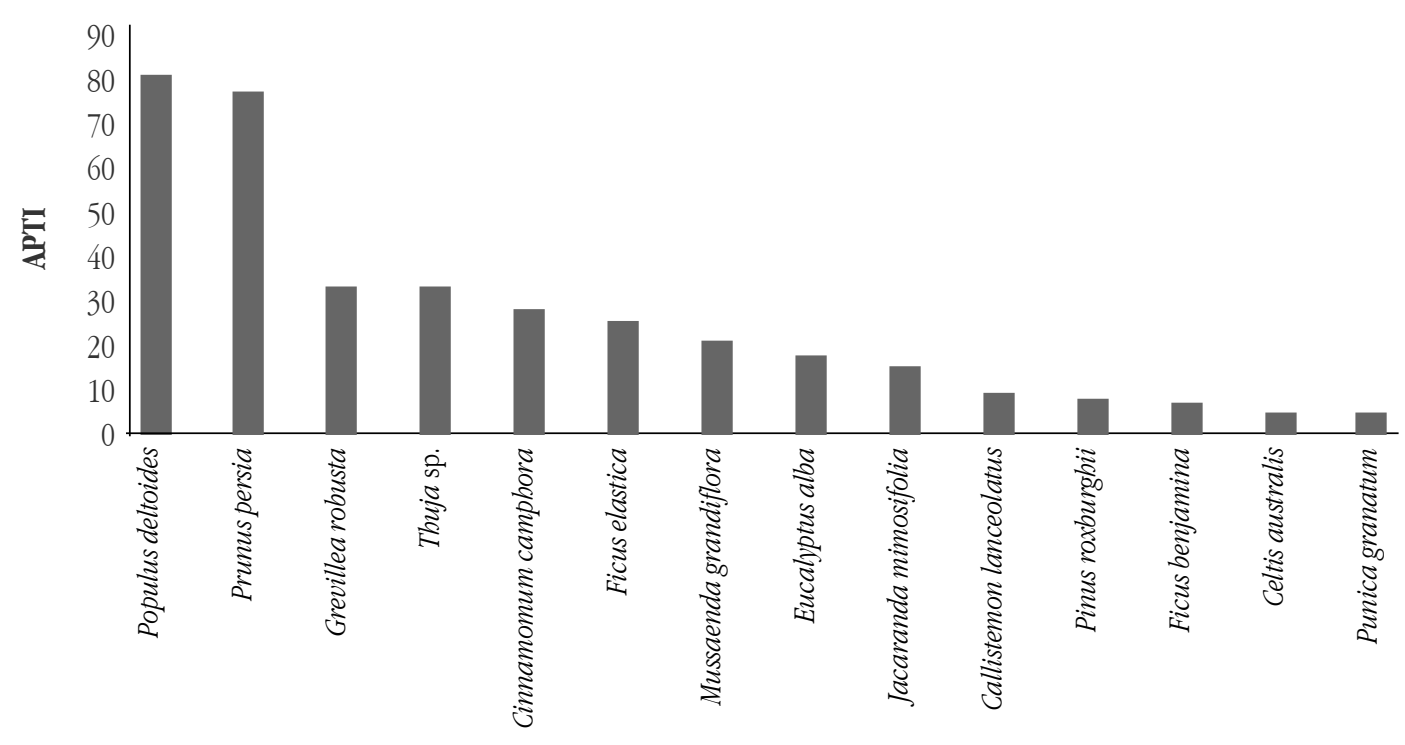

Figure 5 Variation in APTI value in the selected tree species

According to the categorization as in Table 1, the tree species: Jacaranda mimosifolia, Pinus roxburghi, Ficus benjamin, Celtis australis, Alnus nepalensis, Callistemon lanceolatus, Schima wallichi, Pyrus pyrifolia, Celtis australis and Punica granatum fall in the sensitive species to air pollution, whereas Mussaenda grandiflora, Ficus elastica, Cinnamomum camphora and Eucalyptus alba fall in the intermediately tolerant species. Prunus persia, Populus deltoides, Thuja sp. and Grevillea robusta fall in the tolerant category and can effectively be used as sink to air pollution in the polluted sites and the nearby roads for the green belt to enhance air quality and for the abatement of air pollution. On the basis of the tolerance, both the green areas, i.e.

Buddhanilkantha controlled site (APTI ranged from 6.78 to 28.19) and UN Park (availability of higher sensitive species (Callistemon lanceolatus) and inter mediately tolerant species (Jacaranda mimosifolia and Cinnamomum camphora) both fall in the sensitive category.

\section{Conclusions}

Tolerant tree species such as Prunus persia, Populus deltoides and Grevillea robusta with the highest APTI values as observed can be effective roadside vegetation for better absorption and screening of the air pollutants, whereas the sensitive species such as Pyrus pyrifolia, Celtis australis and Punica granatum can act as bio-indicators of air pollutants. The role of the tolerant tree species can be more important near the polluted sites not only to act as an effective sink but also for screening the pollutants. Considering the green belts with more tolerant trees can yield a better result for maintaining air quality. Future studies must focus with relationship with ambient pollutants concentration.

\section{Acknowledgements}

Authors are thankful to ISET-Nepal and GoldenGate Int'l College for financial assistance in the form of research grant.

\section{References}

Abida, B. \& Harikrishna, S. (2010). Evaluation of some tree species to absorb air pollutants in three industrial locations of South Bengaluru, India. E-Journal of Chemistry, 7(1), 151-156.

Arnon, D. I. (1949). Copper enzyme in isolate chloroplasts. Polyphenoloxidase in Beta vulgaris. Plant Physiology, 24(1), 1-15.

Bajaj, K. L. \& Kaur, G. (1981). Spectrophotometric determination of L-ascorbic acid in vegetables and fruits. Analyst, 106 (1258), $117-120$

Bora, M., \& Joshi, N. (2014). A study on variation in biochemical aspects of different tree species with tolerance and performance index. The Bioscan, 9(1), 59-63.

Chinthala, S. \& Khare, M. (2012). Effect of Air Pollutants on Vegetation in Tropical Climate: A Case Study of Delhi City. In M. Khare (Ed.), Air Pollution - Monitoring, Modelling, Health and Control.

Choudhury, P. \& Banerjee, D. (2009). Biomonitoring of air quality in the industrial town of Asansol using the air pollution tolerance index approach. Research Journal of Chemistry and Environment, 13(1), 46-51.

Chouhan, A., Iqbal, S., Maheshwari, R. S. \& Bafna, A. (2012). Study of air pollution tolerance Index of plants growing in Pithampur Industrial area sector 1,2 and 3. Research Journal of Recent Sciences, 1, 172-177.

\section{敨 TU-CDES}


Esfahani, A. A., Amini, H., Samadi, N., Kar, S., Hoodaji, M., Shirvani, M. \& Porsakhi, K. (2013). Assesment of air pollution tolerance index of higher plants suitable for green belt development in East of Esfahan City, Iran. Journal of Ornamental and Horticultural Plants, 3(2), 87-94.

Gharge, S. \& Menon, G. S. (2012). Air Pollution Tolerance Index (APTI) of certain herbs from the site around Ambernath MIDC. Asian J. Exp. Biol. Sci., 3(3), 543-547.

Gidde, M. R. \& Sonawane, P. P. (2012). Assessment of Traffic Related Air Pollution and Ambient Air Quality of Metropolitan Cities (Case Study of Pune City) Journal of Engineering, 2, 1382 1390.

Hill, A. C. (1971). Vegetation: A sink for atmospheric pollutants. Journal of the Air Pollution Control Association, 21(6), 341 . 346.

Hoornweg, D., Sugar, L., \& Gó'97mez, C. L. T. (2011). Cities and greenhouse gas emissions: moving forward. Environment $\mathcal{E}$ Urbanization, 23(1), 207.

Kapoor, B. B. S. \& Bansal, R. (2013). Ascorbic acid contents from some medicinal tree species of Nagaur district of Rajasthan. International Journal of Herbal Medicine, 1 (4), 12-13.

Keller, T. \& Schwager, H. (1977). Air pollution and ascorbic acid. Eur. J. For. Path., 7, 338-350.

Kousar, H., D, N. K., K, P. \& Patel, A. M. (2014). Analysis of Biochemical Parameters as Tolerance Index of some chosen plant species of Bhadravathi Town. International Journal of Environmental Sciences, Vol. 3 (1), 11-16.

Kuddus, M., Kumari, R. \& Ramteke, P. W. (2011). Studies on air pollution tolerance of selected plants in Allahabad city, India. Journal of Environmental Research and Management, 2 (3), 042-046.

Larcher, W. (1995). Physiological Plant Ecology. Berlin: Springer. Lima, J. S., Fernandes, E. B. \& Fawcett, W. N. (2000). Mangifera indica and Phaseolus vulgaris in the Bioindication of Air Pollution in Bahia, Brazil. Ecotoxicology and Environmental Safety, 46, $275-278$

LIU, Y. J. \& DING, H. 2008. Variation in air pollution tolerance index of plants near a steel factory: Implications for landscapeplant species selection for industrial areas. WSEAS Transactions on Environment and Development, 1(4), 24-32.

Makhelouf, A. (2009). The Effect Of Green Spaces On Urban Climate And Pollution. Iran. J. Environ. Health. Sci. Eng, 6, 35 40.

Masuch, G., Kicinski, H. G., Kettrup, A. \& Boos, K. S. (1988). Single and Combined Effects of Continuous and Discontinuous $\mathrm{O}_{3}$ and $\mathrm{SO}_{2}$ Immission on Norway Spruce Needles: I. Histological and Cytological Changes. International Journal of Environmental Analytical Chemistry, 32(3-4), 187-212.
Nowak, D. J., Crane, D. E. \& Stevens, J. C. (2006). Air pollution removal by urban trees and shrubs in the United States. Urban Forestry \& Urban Greening, 4, 115-123.

Pradhan, B. B., Dangol, P. M., Bhaunju, R. M. \& Pradhan, S. (2012). Rapid Urban Assessment of Air Quality for Kathmandu, Nepal: Summary. Kathamandu: ICIMOD.

Pugh, T. A. M., MacKenzie, A. R., Whyatt, J. D. \& Hewitt, C. N. (2012). Effectiveness of Green Infrastructure for Improvement of Air Quality in Urban Street Canyons. Environmental Science E Technology, 46, 7692-7699.

Rai, P. K., Panda, L. L. S., Chutia, B. M. \& Singh, M. M. (2013). Comparative assessment of air pollution tolerance index (APTI) in the industrial (Rourkela) and non industrial area (Aizawl) of India: An ecomanagement approach. African Journal of Environmental Science and Technology, 7(10), 944-948.

Sadeghian, M. M. \& Mortazaienezhad, F. (2012). Selection and identification of air pollution-tolerant plants by air pollution tolerance index (APTI) in urban parks of Isfahan, Iran. African Journal of Biotechnology, 11(55), 11826-11829.

Seyyednjad, S. M., Majdian, K., Koochak, H. \& Niknejad, M. (2011). Air Pollution Tolerance Indices of some plants around industrial zone in South of Iran. Asian journal of Biological Sciences, 4(3), 300-305.

Sharma, M., Panwar, N., Arora, P., Luhach, J. \& Chaudhry, S. (2013). Analysis of biological factors for determination of air pollution tolerance index o selected plants in Yamuna Nagar, India. Journal of Environmental Biology, 34, 509-514.

Shrestha, B. (2001). Air Pollution Status, Kathmandu, Nepal: Institute of Medicine, Tribhuvan University.

Singh, S. K., Rao, D. N., Agrawal, M., Pandey, J. \& Narayan, D. (1991). Air Pollution Tolerance Index of Plants. Journal of Environmental Management, 32, 45-55.

Singh, S. N. \& Verma, A. (2007). Phytoremediation of Air Pollutants: A Review. . In: Environmental Bioremediation Technology.

Thambavani, S., \& Kumar, R. S. (2011). Changes of photosynthetic pigments in some selected plant species induced by cement dust pollution. The Ecoscan, 1, 167 - 172.

Thambavani, S. \& MA, S. (2011). Variation in air pollution tolerance index and anticipated performance index of plants near a sugar factory: implications for landscape-plant species selection for industrial areas. Journal of Research in Biology, 1 (7), 494-502.

Tiwari, R., Cervero, R. \& Schipper, L. (2011). Driving CO2 reduction by Integrating Transport and Urban Design strategies. Cities, 28, 394-405.

Tripathi, A. K. \& Gautam, M. (2007). Biochemical parameters of plants as indicators of air pollution. Journal of Environmental Biology, 28(1), 127-132. 